\title{
A holló és az oroszlán - Bajoni István diplomáciai tevékenysége a 15. század közepén
}

Jelen tanulmányomban egy olyan föpap diplomáciai tevékenységével foglalkozom, aki a humanista müveltségü magyar követek köréhez tartozott és királyi titkárként teljesített követi megbízásai adalékul szolgálnak Mátyás király itáliai diplomáciai kapcsolatainak feltérképezéséhez. Ugyanis Bajoni István lesz Mátyás és Firenze diplomáciai kapcsolatának a „mozgatórugója”.

Bajoni István a Sártiványvecse nemzetségbe tartozó Bajoni család leszármazottja. A Sártiványvecse nemzetségnek ${ }^{1}$ két ága volt, a Poroszlay-ág és a Borsy-Bajoni-ág, melynek kettészakadása után a Bajoni-ágnak központi birtokává válik Bajon. ${ }^{2}$ Bajonnak 1342-ben négy birtokosa is van, melyek közül az egyik a Bajoni család őse, László. Az általa alapított família a 16. században a bihari térség negyedik legnagyobb földbirtokosává válik. ${ }^{3}$ Ezt a tekintélyes pozíciót Zsigmond uralkodása alatt László unokája, Bajoni György alapozta meg, aki az 1403-as felkelés során Zsigmondot támogatta, amiért cserébe az Órévi Lukács váradi püspökkel folytatott hatalmaskodási per során a király támogatását élvezte, ${ }^{4}$ valamint 1412-ben pallosjogot nyert ${ }^{5}$ Stiborici Stibor erdélyi vajda ajánlására. ${ }^{6}$ A pallosjog és az erdélyi vajda ajánlásából látszik, hogy György a király híve volt és jó kapcsolatot tartott fenn az ország egyik tekintélyes urával. Így Zsigmond uralkodásának utolsó évében a Bajoni család rokoni kapcsolatai és vagyona révén a Tiszántúl jómódú középbirtokosai között foglalt helyet. ${ }^{7}$ A Hunyadiak korában Bajoni György István (1411-1471) ${ }^{8}$ nevű fia V. László és I. Ulászló trónért

\footnotetext{
${ }^{1}$ A nemzetség sajátossága Karácsonyi János szerint az, hogy a nemzetség személyneveinek, a Sártivánnak is, a Vecsének is csak a Duna mentén maradt nyoma. Pedig a nemzetségnek jóformán csak Tisza menti vagy tiszántúli ágai ismeretesek. KARÁCSONYI JÁNOS: A magyar nemzetségek a XIV. század közepéig. Bp., 1995. 941. Engel Pál a Borsi-Bajoni-ág közös ősét tünteti fel, és annak négy leszármazottját. A Poroszlay-ág nem szerepel nála. ENGEL PÁL: Középkori magyar genealógia. CD-ROM. Bp., 2001. Sártiványvecse c. tábla.

${ }^{2}$ KARÁCSONYI: i. m., 941.

${ }^{3}$ MAKSAY FERENC: Magyarország birtokviszonyai a XVI. század közepén. Bp., 1990. I. 191.

${ }^{4}$ Zsigmond-kori oklevéltár. I-VII. Szerk.: MÁlYUSZ ELEMÉR - BORSA IVÁN. Bp. 1951-2001. (a továbbiakban: ZsO) II/1. 2172., II/1 3942.

${ }^{5} \mathrm{ZSO}$ III. 2017.

${ }^{6} \mathrm{ZSO}$ III. 2017.

${ }^{7}$ MóDY GYÖRGY: Bajom és a Bajoni család uradalma a középkorban. Biharnagybajom története és néprajza. Szerk.: UJVÁRY ZOLTÁN. Debrecen, 1992. 27-69.

${ }^{8}$ ENGEL: i. m., Sártiványvecse c. tábla.
} 
folytatott harcát kihasználva, gyarapította tovább a család vagyonát, növelve ezzel annak tekintélyét is. Hunyadi János katonájaként szerzett hírnevet magának, Vitéz János familiárisaként pedig István nevü fiát tanítatta. Később Mátyás királyt is támogatta, amiért birtokadományokat kapott. ${ }^{9}$ Békési ispánná ${ }^{10}$ és a váradi püspökség kormányzójává vált. ${ }^{11}$

A társadalmi emelkedésre az udvar nyújtotta a legkedvezőbb lehetőséget. A feltörekvő személynek tehát előbb be kellett jutnia a királyi udvarba, ami befolyásos támogató nélkül nehezen ment. A pártfogó szerepét betölthette egy magas egyházi pozícióba jutott rokon éppúgy, mint valamely nagyúr, akinek a vezető familiárisai közé számított a jelölt. Így eshetett meg, hogy Bajoni István Hunyadi familiárisaként bejuttathatta fiát, Istvánt, mint egyházi személyt és Vitéz pártfogoltját Mátyás király udvarába. Így István feladata az lett, hogy a család politikai pozícióját megtartsa és biztosítsa a királyi udvarban.

Bajoni István tehát egy köznemesi család sarja volt, akinek pontos születési dátumát nem ismerjük. István nevével először egy birtokcsere kapcsán találkozunk, amikor édesapja 1455-ben V. László király előtt Szabolcs vármegyei Naprád és Gaád nevü birtokait elcseréli Szepesi László szintén Szabolcs vármegyében fekvő Ohat, Egyek és Bodach nevü birtokaira. ${ }^{12}$

István humanista müveltségének alapjait a váradi püspök udvarában szerezte meg, majd külföldi tanulmányait is Vitéz fedezte. ${ }^{13}$ Fraknói szerint Ferrarában, majd Bolognában járt egyetemre. Ferrarai tanulmányairól nincs közvetlen adatunk. Azonban Bolognában 1467 júliusában a kánonjog doktorává avatják. ${ }^{14}$ Erről Veress Endre ír részletesebben.

Az 1467. július 9-i bejegyezésből kiderül, hogy István korán megszerzett humanista műveltségének köszönhetően a bolognai egyetem professzorai előtt pozitív benyomást keltett, hiszen a bejegyzés „,nobili et doctissimo viro”-nak nevezi. A forrás alapján úgy ítélem meg, hogy nem járt rendszeresen órákra, mégis a professzorok határozata szerint kánonjogi vizsgára bocsátható, és amikor István jónak látja, ezt a vizsgát le is teheti. Egy nemes és tudós/művelt ember állt előttuik, aki még ráadásul a „Serenissimi regis Ungariae secretario”-ja is. ${ }^{15}$ Ezek szerint már a vizsga elött betöltötte a királyi titkári (secretarius) pozíciót, amelyet nyilván Vitéz János és annak unokaöccse, Janus Pannonius közbenjárásának köszönhetett. ${ }^{16}$

\footnotetext{
${ }^{9}$ FEDELES TAMÁs: A pécsi székeskáptalan személyi összetétele a késö középkorban (1354-1526). (a továbbiakban: FEDELES: A pécsi székeskáptalan ...). Tanulmányok Pécs történetéből 17. Pécs, 2005. 318.

${ }^{10}$ ENGEL: i. m., Sártiványvecse c. tábla.

${ }^{11}$ MÓDY: i. m., 34.

${ }^{12}$ A nagy-károlyi gróf Károlyi család oklevéltára. I-V. (a továbbiakban: Károlyi). Szerk.: GÉRESI KÁLMÁN. Bp., 1882-1897. II. 305-306. CLXXXI. okl.

${ }^{13}$ KRISTÓF ILONA: Személyes kapcsolatok Váradon (1440-1526). Fons, 8. (2001) 1. sz. 6784.

${ }^{14}$ FEDELES: A pécsi székeskáptalan ..., 318-319.

${ }^{15}$ VERESS ENDRE: Olasz egyetemeken járt magyarországi tanulók anyakönyve és iratai 12211864. Bp., 1941. 51. FRAKNÓI VILMOS: Mátyás király magyar diplomatái (VII-ik közlemény). Századok, 23. (1899) 1. sz. 1-9.

${ }^{16}$ FEDELES: A pécsi székeskáptalan ..., 319.
} 
Mátyás idejében csak egy királyi titkár müködött a kancelláriában. ${ }^{17}$ Ö lesz a király bizalmasa, akit tehetsége, nem pedig születése, rokonsága emelt fel. Az 1464-es kancelláriai reform után a secretariusi tisztséget Beckensloer János viseli, de a váradi püspöki székbe való kinevezése után Bajoni István került e fontos pozícióba. ${ }^{18}$ Bónis György feltételezése szerint, mint notarius került be az udvarba, és mindössze néhány esztendeig (1467-1469) látta el a secretariusi teendőket. Ezek föleg diplomáciai missziók voltak. ${ }^{19}$ A legelső secretarius, akire Mátyás trónra lépte után diplomáciai ügyet bízott, Sári Péter volt. 1467 tavaszán azonban Bajoni István indult Rómába. 1467 vége felé Polycarpus György; kancelláriai tag ment Firenzébe, hogy Mátyást felvegyék a Velence ellen kötött ligába; majd 1469-ben újra Bajoni István utazott Firenzébe és Rómába. ${ }^{20}$

Miután az egyetem engedélyezte a kánonjogi vizsgát, 1467. július 13-án István le is vizsgázott. A vizsga végén csak egy elutasítást (reprobatoria) kapott. Ezt is előre megmondta, mert a vizsgáztató tanárok között volt egy tanár, aki rosszindulattal volt iránta (, qui erat sibi inimicus”). Mivel jól felelt a kérdésekre, ezért ettől az egy elutasítástól eltekintve, kihirdették, hogy tudásáról bizonyságot tett, és odaítélték a doktori címet. ${ }^{21}$ Így július végén mint frissen avatott doktor érkezett meg Rómába, hogy a Mátyás által rábízott feladatokat elintézze. Hogy mik voltak ezek a feladatok sajnos nem tudjuk. ${ }^{22}$

Közel egy időben, az 1460-as évek közepén tanult Bolognában ifj. Vitéz János, Váradi Péter és Bajoni István. Ezek az emberek, mivel egymástól nem elszigetelten keruiltek Itáliába, felvették és tartották is egymással a kapcsolatot és nem egyszer szoros barátságok is kialakultak közöttük. Söt a későbbiekben is figyelemmel kísérték és támogatták egymás karrierjét. ${ }^{23}$ Bajoni Váradi Péter állandó barátaihoz és híveihez tartozott. ${ }^{24}$ Vitéz János és Janus Pannonius nem csak a secretariusi hivatalt eszközölte ki a királynál, hanem első római útja után, hazatérését követően a két fópaptól egy-egy kanonoki stallumot is kapott a pécsi és a váradi székeskáptalanban. $^{25}$

Secretariusként még többször járt Rómában. Az utasításokat nem ismerjük, de sejthetjük, hogy a követek, köztük István is, Mátyás rendszeres segélykérelmeit vitték a pápához. Az 1460-as években ugyanis Mátyás elsődleges diplomáciai partnerei az itáliai államok voltak, melyek jelentős összegekkel támogatták a magyar király törökellenes hadjáratait. ${ }^{26}$ Ezekről a különféle támogatásokról Janus

\footnotetext{
${ }^{17}$ SZILÁGYI LORÁND: A magyar királyi kancellária szerepe az államkormányzatban: 14581526. Bp., 1930. 11.

${ }^{18}$ BÓNIS GYÖRGY: A jogtudó értelmiség a Mohács elötti Magyarországon. Bp., 1971. 226. SZILÁGYI: i. m., 12.

${ }^{19}$ BÓNIS: i. m., 226.

${ }^{20}$ SZILÁGYI: i. m., 82.

${ }^{21}$ VERESS: i. m., 51.; FRAKNÓI V.: Mátyás diplomatái ..., 4.

${ }^{22}$ VERESS: i. m., 245.

${ }^{23}$ KRISTÓF: i. m., 79.

${ }^{24}$ FRAKNÓI VILMOS: Egyháznagyok a magyar középkorból. Bp., 1916. 169.

${ }^{25}$ FEDELES: A pécsi székeskáptalan ..., 319.

${ }^{26}$ TeKE ZsUZSA: Mátyás és Firenze. http://www.matud.iif.hu/08dec/08.htm (a letöltés ideje: 2014. szeptember 1.)
} 
Pannonius egyik epigrammájában a következőképpen emlékezik meg: „Róma adója arany, selymét ideküldi Velence,/ Bari lovat szállít, fegyvereket Genua./ Végre Firenze maradt egyedül, ö még nem adózott. ${ }^{\text {"27 }} \mathrm{Az}$ epigrammából kiderül, hogy az 1460-as évek első felében Firenze se pénzzel, se katonákkal nem támogatta a török elleni harcokat. Ennek oka, hogy az említett időszakban Firenze a török szultán, II. Mehmed, támogatását élvezte, és az Oszmán Birodalommal folytatott kereskedelemnek köszönhetően törökbarát politikát folytatott. Ez a „barátság” azonban 1467-ben átmenetileg megszakadt a pápa és az itáliai közvélemény nyomására, lehetőséget adva így Mátyásnak a közeledésre. Firenze a török elleni háborúkban való részvételt elutasította, de a magyar követeket mindig szívélyesen fogadta. Ezt Mátyás követei is megtapasztalhatták, amikor a pápához vitték az uralkodó segélykérelmét, és menet-jövet megfordultak Firenzében. ${ }^{28}$

1469 februárjában Bajoni István Rómába tartó útja során felkeresi Mátyás király levelével Firenzét, melyben Mátyás barátságáról és jóindulatáról biztosította a városállamot. ${ }^{29}$ Mint ahogy első, úgy második római követségének részleteiről sem tudunk semmit. Ebből az időből csupán érdekes vadászkalandjának emléke maradt ránk, ${ }^{30}$ valamint egy pápai felhatalmazás, melynek értelmében egyszerre több egyházi javadalmat is bírhatott. ${ }^{31}$

A Tiberis mentén esett vadászkalandjából, mely közismert, csupán annyit emelnék ki, Bajoni testi adottságait megvilágítva, hogy a szarvast, mely rátámadt, ökleivel verte le. ${ }^{32} \mathrm{E}$ tettét Janus Pannonius elégiában örökítette meg, ami így szól István erejéröl: „Nagy Pallas könyörül meg, s felfegyverzi barátját:/ mennyei szent kardot fog remegö keze már./ Oly nagy erö van benne, hogy egyet sújt, s az agancsos / két lábat veszt el, célbatalál a csapás./ Ekkor, a küzdelmet bár felveszi hasztalan újra, / végre lerogy, vaskos teste a földre zuhan." ${ }^{33}$ Ezek szerint István nem csak nemes, tudós férfi volt, hanem bátor és harcedzett is. Hiszen a középkor folyamán a vadászat is a kanonokok életmódjához tartozott, így nem állt távol tőlük a kardforgatás sem. ${ }^{34}$

István Rómából jövet 1469 júniusában újra megállt Firenzében, és tájékoztatta a várost Mátyás csehországi győzelméről ${ }^{35}$ Ez a dicső győzelem jó lehetőséget adott arra, hogy Firenze kifejezze jóakaratát Mátyás irányába, és ajándékkal kedveskedjen neki. Firenze ugyanis két élö oroszlánt: egy hímet és egy nőstényt küldött

\footnotetext{
${ }^{27}$ De iisdem ad eundem. Janus Pannonius összes munkái. (a továbbiakban: PANNONIUS: i. m.) Szerk.: V. KOVÁCS SÁNDOR. Bp., 1987. 235-236.

${ }^{28}$ TEKE: i. $\mathrm{m}$.

${ }^{29}$ Uo.

${ }^{30}$ VERESS: i. m., 245.

${ }^{31}$ FRAKNÓI: Mátyás diplomatái ..., 4.

${ }^{32}$ VERESS: i. m., 245. FRAKNÓI: Mátyás diplomatái ..., 4-5.

${ }^{33}$ De venatione Stephani de Baion oratoris. PANNONIUS: i. m., 382-385.

${ }^{34}$ FEDELES: A pécsi székeskáptalan ..., 161.

${ }^{35}$ TEKE: i. $\mathrm{m}$.
} 
Mátyásnak ajándékba. ${ }^{36}$ Erről az eseményről a firenzeiek levele, ${ }^{37}$ Mátyás válasza ${ }^{38}$ és négy Janus Pannonius epigramma tudósít. ${ }^{39}$

De miért éppen oroszlánokat küldtek a firenzeiek? Az ajándék kiválasztásában Bajoni Istvánnak jelentős szerepe volt. Mint Mátyás secretariusa és bizalmasa ismerhette az uralkodó vágyait, így Firenzében időzve elmondta, hogy Mátyás nagyon szereti ezeket az állatokat. ${ }^{40}$

Bonfini is megemlíti a koronázási ünnepség leírásánál, hogy Mátyás udvarában oroszlánvadászatok és gladiátorviadalok is estek olykor-olykor, s bennük a királynak nagy gyönyörüsége telt. ${ }^{41}$ Csánki Dezső szerint nem tudhatjuk biztosan, hogy eleven oroszlánokkal űzött cirkuszi játékokra céloz-e Bonfini vagy pedig álarcos színészekre. Annyi bizonyos, hogy mint más európai fejedelem, Mátyás is tartott udvarában szelídített oroszlánokat. ${ }^{42}$

Az oroszlánokkal érkező kísérőlevél elmondja azt is, hogy Firenze számára miért olyan fontos ez az állat, és miért tartja méltó ajándéknak. Először: ennek az állatnak a jelleme hasonlít a legjobban egy király jelleméhez. Ahogy a király parancsol a népnek és az embereknek, úgy parancsol az oroszlán is saját fajtájának. ${ }^{43}$ Ez némi hízelgés Mátyásnak. Másodszor: az oroszlánok szimbolikus ajándékával nagyobb ajándékot nem is küldhetett volna Firenze, mert a firenzei nép a magyar királynak így saját régi jelét/jelképét (insigne) adta. ${ }^{44}$ Harmadszor: a levél utal a két állam korábbi kapcsolatára is, amikor elmondja, hogy Mátyás elődei sokat tettek azért, hogy a firenzei nép megörizhesse szabadságát, melynek jelképe szintén az oroszlán. ${ }^{45} \mathrm{Az}$ általuk küldött oroszlánok, zálogként (pro pignore), azt a célt

${ }^{36}$ „... cogitavimus duorum leonum munus ad te mittere.” - „Mittimus igitur ad te duos leones marem et feminam." Mátyás király levelei: külügyi osztály (a továbbiakban: Mátyás levelei). Közzéteszi FRAKNÓI VILMOS. Bp., 1893-1895. I. 241-242. 177. sz. levél.

${ }^{37}$ Uo. 241-242. 177. sz. levél.

${ }^{38}$ Uo. 243. válaszlevél.

${ }^{39}$ PANNONIUS: i. m., 235-236.

${ }^{40}$, ,... oportune admodum Stefanus de Baion admonuit leones tibi esse cordi et videre te percupide illud genus." Mátyás levelei, 241. Horváth Alice a következőképpen fogalmaz: „Ö tolmácsolta Firenzében Mátyás királynak azt a kívánságát, hogy oroszlánokat szeretne kapni." HORVÁTH ALICE: Báthory Miklós váci püspök (1474-1506) élete és kora. A Váci egyházmegyei gyüjtemény kiállításán bemutatott tárgyak és dokumentumok katalógusa. Vác, 2006. 68.

${ }^{41}$ ANTONIO BonfinI: A magyar történelem tizedei. Bp., 1995. 740. 4.1.15.

${ }^{42}$ CSÁNKI DEZSÖ: I. Mátyás udvara. Századok, 17. (1883) 750-785.

${ }^{43}$ „Habent igitur illi quidem cum regibus similitudinem quandam. Quemadmodum enim vos gentibus atque hominibus imperatis, ita et illi sue genti et generi imperitant.” Mátyás levelei, 241-242. 177. sz. levél.

${ }^{44}$ „Neque est, si recte quis inspexerit, quod Florentinus ad te populus mittere posset maius; namque sub tali insigni et a principio constituta libertas nostra est et defensa atque aucta ad hanc usque diem. Admodum autem convenienter vetustum suum insigne Florentinus populus ad Ungarorum regem dono mittet.” Uo. 242.

${ }^{45}$,Fuit enim populoFlorentino pervetusta cum regibus Ungharis amicitia, et multa extant merita progenitorum tuorum antiquorum regum in urbem et libertatem nostram, cuius insigne leo est. Nos tecum eandem, que cum tuis progenitoribus et regibus Ungharis, esse cupimus." Uo. 242. 
szolgálják, hogy a két állam közötti régi baráti viszony továbbra is fennmaradjon, ${ }^{46}$ valamint hogy méltó ajándékkal hódoljanak Mátyás előtt, gratulálva a csehek felett aratott győzelemhez is.

Az oroszlán azonban nemcsak a firenzei nép szabadságának a jelképe, hanem a cseh király címerállata is. Hogy mi késztette Mátyást a cseh korona megszerzésére, az köztudott, de lépjünk ki egy pillanatra a hagyományos történelmi felfogásból.

A szakirodalom szerint Mátyás számára az volt az elsődleges, hogy egy igen stabil hatalmi koncentrációt, egy szövetségi rendszert, egy közép-európai és a német birodalom keleti tartományait is magában foglaló ligát szervezzen meg. Politikai tőkét kívánt kovácsolni morva és sziléziai tartományaiból, amelyre későbbi szélesebb európai diplomáciájában építeni akart. ${ }^{47}$ Janus Pannonius epigrammája jelét adhatja annak, hogy mennyire tisztában voltak ezzel akkoriban a firenzeiek, és maga Janus Pannonius is. „Mit! Hogy most cseh királyok címere dísze ez állat? / Új birodalmat nyersz, annak a jósjele ez."48 Így Firenze - az oroszlánok küldésével és a magyar humanisták korán megjelenítették elvárásaikat Mátyás hatalmi aspirációival szemben. Az imperátori címet pedig maga Janus Pannonius is meglebegtette elötte. ${ }^{49}$

Ugyanakkor nem osztom azt a vélekedést, mely szerint Firenze városállama két oroszlánszobrot kívánt küldeni Mátyásnak. ${ }^{50} \mathrm{Az}$ általam áttekintett források és szakirodalmak $^{51}$ alapján úgy vélem, nem csak kívánt, hanem küldött is, és nem oroszlánszobrokat, hanem két élő oroszlánt. ${ }^{52}$

${ }^{46}$ „Accipies igitur hoc munus nostrum, retinebisque pro pignore animi et observantie nostre erga te et maiestatem tuam." Uo. 242.

${ }^{47}$ ATTILA BÁRÁNY: „Matthias’ European Diplomacy in the 1480s”. Matthias and his legacy. Cultural and political encounters between East and West. Eds. Attila Bárány - Attila Györkös. Speculum Historiae Debreceniense. A Debreceni Egyetem Történelmi Intézet Kiadványai 1. Debrecen, 2009. 363-392.

${ }^{48}$ De leonibus per florentinos missis, ad Matthiam regem. PANNONIUS: i. m., 235.

${ }^{49}$ PAJORIN KLÁRA: Az első humanisták, a hatalmi reprezentáció korai ösztönzői Mátyás udvarában. Hunyadi Mátyás, a király. Hagyomány és megújulás a királyi udvarban 1458 1490. Kiállítási katalógus. Bp., 2008. 139-145.

${ }^{50}$ FeDELES: A pécsi székeskáptalan ..., 116.; FedELES TAMÁs: Személyi összefonódások Pécsett, Mátyás és a Jagellók idején. Püspökök, prépostok, kanonokok (Fejezetek Pécs középkori egyháztörténetéből). Szerk.: FEDELES TAMÁS. Szeged, 2010. 132.

${ }^{51}$ FrAKNói VILMOS: Hunyadi Mátyás király 1440-1490. Bp., 1890. 203.; CsáNKI DEZsÖ: I. Mátyás udvara. Bp., 1884. 49.; BALOGH JoláN: A müvészet Mátyás király udvarában. Bp., 1966. I. 681.; PAJORIN: i. m., 143.

${ }^{52}$, ,Mittimus igitur ad te duos leones marem et feminam.”; „Leones, quos vestra civitas nobis dono misit, ...” Uo. 243. „... cum ob earum ferarum missionem ...” Mátyás levelei, 241242. 177. sz. levél. 
Az oroszlánokkal és a kísérő levéllel Garázda Péternek ${ }^{53}$ kellett volna útra kelnie, helyette azonban ${ }^{54}$ Thelegdi János ${ }^{55}$ érkezik meg Bécsbe ${ }^{56} 1470$ februárjában. Nem a véletlen müve az, hogy Mátyás itt veszi át az állatokat. Szimbolikusan érzékeltetni akarja a császárváros lakóival és III. Frigyessel, hogy Firenze hódol előtte, és a világi uralkodók uralkodójánál, vagyis a császárnál is különbnek ismeri el őt. ${ }^{57}$ Bajoni István nincs jelen az ajándék átadásánál. 1469 decemberében még Firenzében tartózkodott, majd onnan 1470 januárjában Velencébe ment. ${ }^{58}$

Az ajándékot a király levélben köszönte meg, melyet nevében feltehetően Janus Pannonius fogalmazott meg. ${ }^{59}$ A levél első része tájékoztatja a firenzeieket arról, hogy az ajándék épségben megérkezett, és Thelegdi „,kevés, de jóindulattal és finom ízléssel teli szót szólva” (P. E. fordítása) az oroszlánokat átadta. ${ }^{60}$

A levél folytatásából kiderül, hogy Mátyás megértette az ajándék szimbolikus jelentését, mellyel a firenzeiek egyértelmúen megüzenték, hogy hajlandóak a régi barátságot feleleveníteni és diplomáciai összeköttetést létesíteni a magyar királysággal. A válaszlevélben megfogalmazott köszönet Mátyás további célját is elénk tárja. ,Egész államotokat felajánlottátok nekünk, hogy a barátság, ami egykor a mi és a ti öseitek között kölcsönösen élt, most egyszerre közöttünk is új kezdetet

\footnotetext{
${ }^{53}$ Garázda Péter feltehetőleg 1443-ban született a Tolna megyei Aparon, a Vojk nemből származó és Szlavóniában nagy birtokokkal rendelkező családba. Felmenői részt vettek Zsigmond uralkodása elején a király törökellenes vállalkozásaiban, amiért az uralkodótól armálist kaptak. A címeres levelet Keresztúri Garázda Miklós, Péter nagyapja, és Szilágyi László 1409-ben megújíttatták. A család rokonságban állt Vitéz Jánossal; akinek édesanyja Garázda leány, Péter pedig Janus Pannonius másod-unokafivére volt. Ferrarában, majd hosszú ideig Firenzében tanult. Janus 1465-ös római útja alkalmával meglátogatta, majd a pápánál egy szerzetesi javadalmat eszközölt ki számára, tanulmányi költségeinek fedezésére. 1478-ban olvasókanonok Pécsett. FEDELES: A pécsi székeskáptalan ..., 358-359.

${ }^{54}$ Garázda Péter 1471. november 22-én levelet küldött Lorenzo de' Medicihez, melyben megindokolja, hogy miért nem tudta a rábízott feladatot végrehajtani. „A véletlen úgy hozta, hogy ajándékodra várva Velencében súlyosan megbetegedtem. ... Noha az egész ügyben semmit sem mulasztottam el, amit tekintélyed öregbítése érdekében helyesnek láttam, hiába, csak bosszantott, már temiattad is, hogy éppen akkor kötött ágyhoz a betegség, s így pazar ajándékodat nem kézbesithettem személyesen a címzetteknek, ...” Magyar humanisták levelei a XV-XVI. században. Szerk.: V. KoVÁCS SÁNDOR. Bp., 1971. Nr. 221. 415-416.

${ }^{55}$ Thelegdi János Garázda Péter barátja volt. Garázda Péter betegsége miatt ö fogja kézbesíteni Mátyásnak az ajándékot. A Zala vármegyében fekvő azonos nevű településről származott, vélhetőleg kisbirtokos nemes családból. Javadalom szerzésében bizonyosan szerepet játszhatott Garázdával - és általa vélhetőleg Janusszal - fennálló kapcsolata. 1470 1477-ben kanonok Pécsett. FedELES: A pécsi székeskáptalan ..., 455-456.

${ }^{56}$ Balogh Jolán szerint ezt az ajándékot Thelegdi Budára vitte. BALOGH: Mủvészet Mátyás udvarában ..., 681.

${ }^{57}$ PAJORIN: i. m., 143.

${ }^{58}$ FRAKNÓI: Mátyás diplomatái ..., 5.

${ }^{59}$ PAJORIN: i. m., 143.

${ }^{60}, \ldots$ et pauca insuper vestro nomine referens addidit, sed plena benevolentie et humanitatis.” Mátyás levelei, 243. 177. sz. levél. Fordítását (a fordítás Boronkai Ivántól származik) közölte V. Kovács Sándor. Magyar humanisták levelei .., 240. Nr. 110. Ugyanezt a fordítást közli még: Mátyás és a humanizmus. Szerk.: CsukoviTs ENIKÖ. Bp., 2008. 147.
} 
vegyen ennek az új zálognak a közbenjárásával, ami olyan, mint egy elöjáték (preludio). "61 (P. E. fordítása) Kiemelném az „előjáték” szót. Amivel a válaszlevél írója Mátyás azon célját szeretné jelezni, hogy nem csupán barátságra számít a magyar uralkodó, hanem arra, hogy ezt a kapcsolatot egy erős államszövetséggé tudja átalakítani. Erre utal az alábbi levélrészlet is: „Ennélfogva igen szívesen fogadunk mindent; de sokkal szívesebben a jelzettet, mint a jelet, a testet, mint az árnyékot, a lényeget, mint a külsöt. Felajánljuk nektek cserében a mi barátságunk kívánt és elökészített böségét vagy a szorosabb jóakarat kötelékére való szándékot." 62

Az 1469-1470-es években újabb háború robbant ki Itáliában. Nagy valószínűséggel ennek köszönhető Firenze nyitása a magyar uralkodó felé. Ugyanis a békekötést követően (1470 júliusában) Firenze távolodik Mátyástól, Mátyás diplomáciájában pedig az 1470-es években újabb irányváltás figyelhető meg, melynek köszönhetően Milánó és Nápoly kerül előtérbe, a Firenzével tervezett szövetség megkötése pedig elmarad. ${ }^{63}$

Az 1469-1470-es években állandóan alakult és változott a firenzei-magyar kapcsolat. Az ezt befolyásoló személyek közül hármat emelnék ki. Vitéz Jánost, esztergomi érseket. Janus Pannoniust, aki 1461-ben nyerte el „a királyné fökancellárja" tisztet, de Vitéz János mellett alkancellárként is szerepelt, külpolitikai ügyeket intézett, diplomáciai iratokat fogalmazott az úgynevezett „nagyobbik” kancelláriában. Bajoni Istvánt, aki Vitézzel és Janus Pannoniusszal szoros összekötetésben állt. Általuk került be a királyi udvarba, vált királyi titkárrá, és diplomatává. Követként jó szolgálatot tett Firenzének, mégis 1470-es velencei követsége után diplomáciai tevékenységéről nincsenek információink. Talán belekeveredett az 1471-es Vitéz-féle összeesküvésbe, melynek következtében hivatalnoki karrierje megszakadt, egyházi pályája azonban felfele ívelt.

Bár mind a három férfi sokat tett a firenzei-magyar szövetség létrejöttéért, ennek ellenére a holló által a firenzei oroszlánnal tervezett szövetség meghiúsult. Így fáradozásaiknak nem lett eredménye.

\footnotetext{
${ }^{61}$ „Agimus igitur vobis gratias haud vulgares, cum ob earum ferarum missionem, que profecto et perrare sunt, nostris presertim in locis, et habent certam, velut ipsi etiam attigistis, nobiscum, hoc est cum regibus similitudinem; tum vero longe magis ob id, quod tali munere significari voluistis totam videlicet rempublicam vestram in hoc suo vetusto insigni nobis esse oblatam, ea mente, út amicitia que inter nostros et vestros maiores olim mutua viguit, simul etiam inter nos huius novi pignoris interventu et quasi quodam preludio novum resummat initium.” Mátyás levelei, 243. 177. sz. levél; Magyar humanisták levelei ..., 240. Nr. 110. Mátyás és a humanizmus, 147.

${ }^{62}$,Quapropter accipimus perlibenter omnia; multo tamen libentius signatum quam signum, corpus quam umbram, rem quam figuram; offerentes vobis et nos e contra desideratam nostre necessitudinis copiam et paratam vel ad arctioris benevolentie vincula voluntatem." Mátyás levelei, 243. 177. sz. levél; Magyar humanisták levelei ..., 240. Nr. 110.; Mátyás és a humanizmus, 147.

${ }^{63}$ TEKE: i. m.
} 